\title{
Pathology and morphology of Ichthyophonus hoferi in naturally infected fishes off the Swedish west coast
}

\author{
Hassan Rahimian* \\ University of Göteborg, Dept of Marine Ecology, Kristineberg Marine Research Station, S-450 34 Fiskebäckskil, Sweden
}

\begin{abstract}
The pathology and morphology of Ichthyophonus hoferi was studied in naturally infected Atlantic herring Clupea harengus, in sprat Sprattus sprattus, and in flounder Pleuronectes flesus from the west coast of Sweden. The pathogen was found in all organs examined, with the intensity of infection varying in different organs of the different fish species. Two main phases in the life of infecting parasites were identified, 'active' and 'passive', the latter being able to switch to active. The active phase of the infection in herring was usually accompanied by a lean and slender appearance of the body, a drastic decrease in intestinal fat, emaciation of the somatic muscles, swelling of the visceral organs, poor quality of flesh texture and a distinctive off-odour. The most characteristic macroscopic sign of ichthyophonosis in herring and flounder was the occurrence of creamy white nodules on the heart. The infection causes a chronic systemic granulomatous inflammation. The nature of the granulomatous inflammation was host- and tissue-dependent. The pathogenicity of the parasite in its active form and the side effects of host defence cells were also reflected in dramatic tissue damage and loss of structure and function of the infected organs. Three kinds of spores were identified: 'un-developing spore', 'developing spore' and 'plasmodio-spore' The formation and spread of 'plasmodia', from plasmodiospores, as a secondary infection agent is documented. Transmission electron microscopy revealed I. hoferi to be multinucleated, containing different organelles and structures. These included a cell wall, an undulating cell membrane, a thin paramural endoplasm, an endoplasmic reticulum, polymorphic but usually spherical mitochondria with short tubulo-vesicular cristae, dictyosomes with plate-like cristernae, large electron-dense lipid droplets and electron-lucid vacuoles, probably containing glycogen.
\end{abstract}

KEY WORDS: Ichthyophonus hoferi Morphology - Pathology · Herring - Sprat $\cdot$ Flounder $\cdot$ North East A.tantic

\section{INTRODUCTION}

Since its original description, Ichthyophonus hoferi Plehn \& Mulsow, 1911, has been subjected to name and taxonomic changes. The history of the controversial nomenclature of $I$. hoferi is well documented by Lauckner (1984). Based on microscopic structure and its in vivo characters, I. hoferi has been recognised as a fungus by most of today's parasitologists. Doubts, however, have been expressed about its taxonomic position. Recent independent research suggests a new, as

-Address for correspondence: Department of Zoology, Box 463, S-405 30, Göteborg, Sweden. E-mail: h.rahimian@zool.gu.se yet unnamed, clade of protistans to which $I$. hoferi belongs (Ragan et al. 1996, Spaggaard et al. 1996).

Ichthyophonus hoferi has been reported from close to 100 species of freshwater, estuarine and marine teleosts in temperate as well as in tropical habitats and the list is still growing (Rand 1990).

Ichthyophonus hoferi causes a systemic granulomatous infection in its hosts (McVicar \& McLay 1985). Moreover, the invasion of the hosts by this parasite commonly represents a 'dead end' in the life cycle of the host (Noga 1990). In herring from the North Atlantic, for instance, 'acute' infection characterised by massive tissue invasion and necrosis led to the death of the host between 30 and $180 \mathrm{~d}$ after infection (Sindermann \& Scattergood 1954, Sindermann 1990, 
Rahimian \& Thulin 1996), depending on whether the disease was 'acute' or 'chronic'. The tissue responses of experimentally infected rainbow trout and naturally infected plaice and haddock to 1 . hoferi have been described by McVicar \& McLay (1985). The disease in the western North Atlantic herring has been described as systemic, with foci of infection in the heart, viscera and red musculature (Sindermann 1990). 'Chronic infection' is exhibited by cell infiltration, progressive connective tissue encapsulation of spores, and sometimes accumulation of melanophores. The 'acute' phase of the infection in west Atlantic herring has been reported as consisting of multiple germination of thickwalled spores, 'hyphal' invasion of host tissues, and replacement of tissues by the organism's mass. This phase of the disease is accompanied by gross external and internal signs, including roughened skin ('sandpaper effect') and white nodules on the heart and liver (Sindermann \& Scattergood 1954).

After an outbreak of Ichthyophonus hoferi in Atlantic herring Clupea harengus stocks off the Swedish west coast during August/September 1991 and thereafter (Rahimian \& Thulin 1996), histo-pathological studies were carried out on several commercially important fish species of the area. The present paper aims to describe the pathology and morphology of $I$. hoferi, as found in naturally infected marine fishes.

\section{Nomenclatural remarks}

Ichthyophonus hoferi has so far been considered to be a fungus of unknown taxonomic position. The new findings (Ragan et al. 1996, Spaggaard et al. 1996) suggest a non-fungal nature for $I$. hoferi. Consequently, some changes in the nomenclature of this organism are inevitable. According to Webster's Dictionary the 'hypha' is 'any of the threadlike parts making up the mycelium of a fungus'. This definition contrasts with the findings of the present study as well as with those of Ragan et al. (1996) and Spaggaard et al. (1996). In the light of new findings the author proposes the term 'pseudohypha' as an alternative to 'hyphae' in the present paper. The term 'spore' is still valid and can be retained. In describing the fine structure of $I$. hoferi the nomenclature is in accordance with that of Rand (1990) and Bozzola \& Russell (1992).

In the present paper the terms 'active' and 'passive', referring to the 2 distinct phases of the parasite life in fish infected with Ichthyophonus hoferi, are preferred. The definitions for these terms, based on the author's observations, are as follows: 'Active' is a phase in which the pathogen usually grows and spreads within the host with no, or little, microscopically detectable reaction from the host. In the 'passive' phase, on the other hand, the pathogen is surrounded by inflammatory cells and/or cellular or finely granular necrotic debris. In this phase no signs of growth or development of $I$. hoferj could be detected. Other characteristics of these 2 phases are described in the 'Results' and 'Discussion' sections. These 2 phases are considered as parts of the parasite life cycle in the host and are different from 'acute' and 'chronic', which refer to the host immunological reactions or the state of the disease.

\section{MATERIAL AND METHODS}

The fish species examined were Atlantic herring Clupea harengus, sprat Sprattus sprattus, flounder Pleuronectes flesus, mackerel Scomber scombrus, pollack Pollachius pollachius, saithe Pollachius virens, whiting Merlangius merlangus, plaice Pleuronectes platessa and dab Limanda limanda (see Table 1). Herring was sampled from several localities in the Kattegat-Skagerrak and the Sound and the remainder were sampled from Gullmarsfjord and Brofjorden, on the west coast of Sweden (Fig. 1). Fish were caught by bottom trawl.

The examination of the fish was performed in 4 steps. First the body, fins and branchial cavity were examined for gross signs of ichthyophonosis. Second,

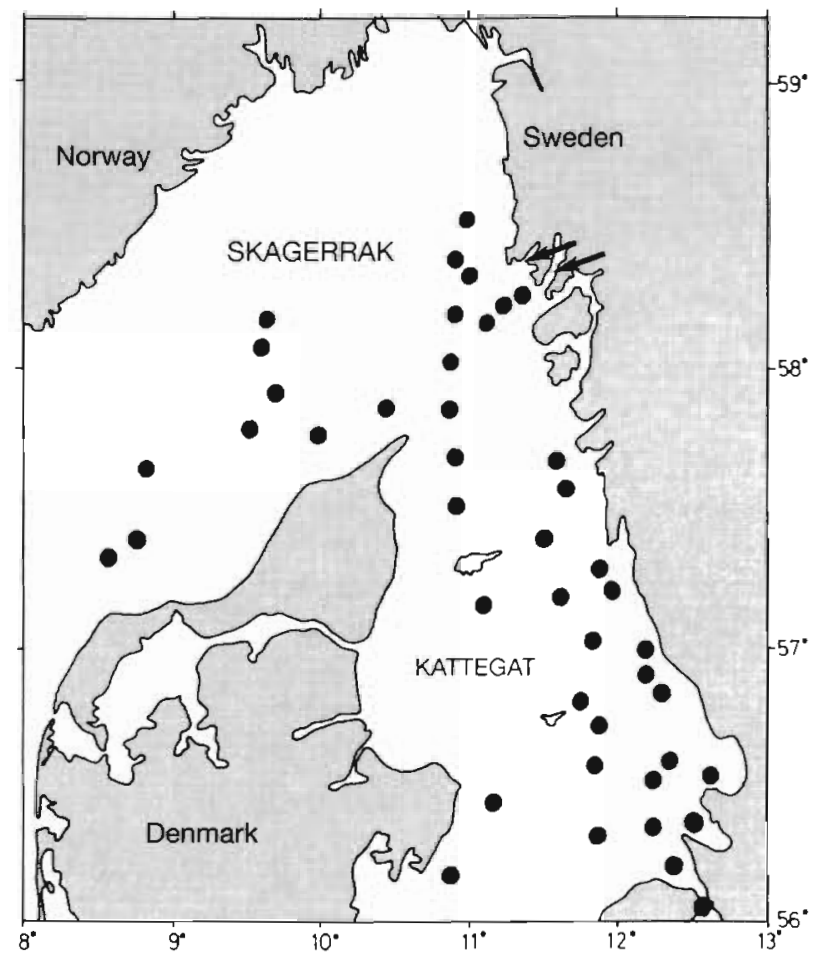

Fig. 1. Sampling area and sampling sites for different fish species. (-) Sampling sites for herring. Arrows: sampling areas for the other species 
the body and pericardial cavity were opened and inspected for single or multiple confluent whitish nodules. During the third step, squash preparations of lateral musculature system, heart, liver, kidney, spleen and brain were made and microscopically screened for spores and/or pseudohypha of Ichthyophonus hoferi. If positive, those organs were then fixed for pathological and fine-structural investigations. Tissues were fixed in Bouin's solution. Serial sections were made and stained either in haematoxylin-eosin (H\&E; Humason 1979), periodic acidSchiff (PAS; Lillie 1951) or May-Gründwald-Giemsa (Yasutake \& Wales 1983). A total of 670 spores were measured using calibrated eyepieces.

For transmission electron microscopy pieces of the heart, liver and spleen of infected herring and flounder were fixed in $3 \%$ glutaraldehyde in $0.1 \mathrm{M}$ sodium cacodylate $\left(\mathrm{pH} 7.4,4^{\circ} \mathrm{C}\right)$, washed in $0.1 \mathrm{M} \mathrm{Na}$ cacodylate $(\mathrm{pH} 7.4)$ and post-fixed in $2 \%$ phosphate buffer $\mathrm{OsO}_{4}$, dehydrated, and embedded in epon and sectioned. The sections were screened using a Zeiss EM 902A transmission electron microscope.

In order to detect significant differences, 1-way factorial analysis of variance (ANOVA) $(\alpha=0.05)$ and the post-hoc Scheffé test were performed using Sataview 4.05 .

\section{RESULTS}

Ichthyophonus hoferi was found in 3 of the 9 fish species. These were herring, sprat and flounder (Table 1).

During gross examination, creamy white nodules (ranging from $<0.5 \mathrm{~mm}$ to up to $10 \mathrm{~mm}$ in diameter) were found on the internal organs while no sign of infection was found on the body surface. The appearance of nodules was the same in many infected specimens of all 3 species, but nodules on the heart of herring were sometimes joined together to form 'giant nodules' (Fig. 2). Sprat also showed the same gross

Table 1. List of microscopically examined fish and the prevalence of ichthyophonosis in each fish species

\begin{tabular}{|llc|}
\hline Fish species & Common name & $\begin{array}{c}\text { No. examined } \\
\text { (prevalence \%) }\end{array}$ \\
\hline Clupea harengus & Atlantic herring & $9240(4.2)$ \\
Sprattus sprattus & Sprat & $77(11.7)$ \\
Pleuronectes platessa & Plaice & $33(0.0)$ \\
Pleuronectes flesus & Flounder & $120(17.0)$ \\
Limanda limanda & Dab & $30(0.0)$ \\
Scomber scombrus & Mackerel & $108(0.0)$ \\
Pollachius pollachius & Pollack & $5(0.0)$ \\
P. virens & Saithe & $10(0.0)$ \\
Merlangius merlangus & Whiting & $35(0.0)$ \\
& & \\
\hline
\end{tabular}

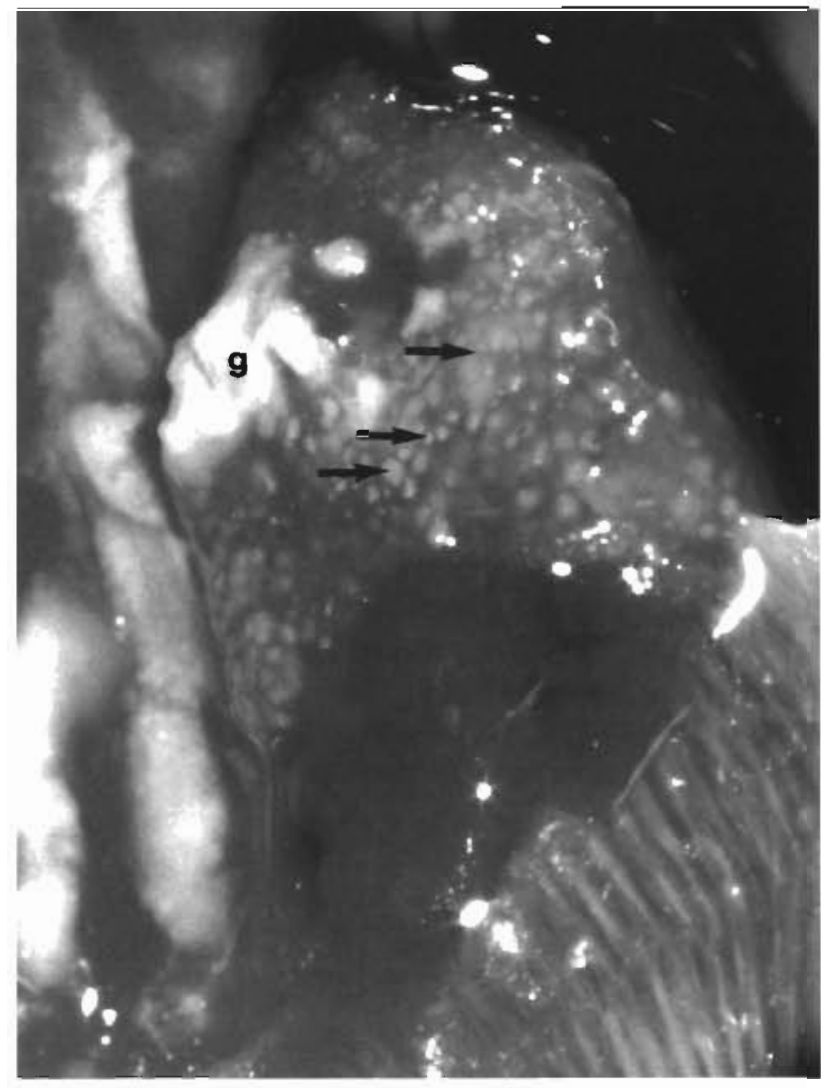

Fig. 2. Gross sign of ichthyophonosis on the heart of heavily infected herring. The heart is covered by small (arrows) and giant $(g)$ nodules

signs of infection as herring. The size of the nodules in flounder, on the other hand, was generally smaller than in herring. A cut into any of the heavily infected organs revealed a generalised distribution of nodules in the organs. Heavily infected specimens were found to be emaciated and their fat reserve had been drastically reduced.

Some herring obtained from commercial catches off the Norwegian Deeps showed black spots in and on their fillets which on microscopical examination were shown to be melanization around spores of Ichthyophonus hoferi.

\section{Squash preparation}

The most commonly observed and characteristic features of squashed infected organs were the spores of Ichthyophonus hoferi, sometimes accompanied by pseudohypha growing out of the spores. The abundance of pseudohyphae was directly correlated to time post-mortem. If this was short, i.e. less than $10 \mathrm{~h}$ at room temperature, spores and only occasional pseudo- 


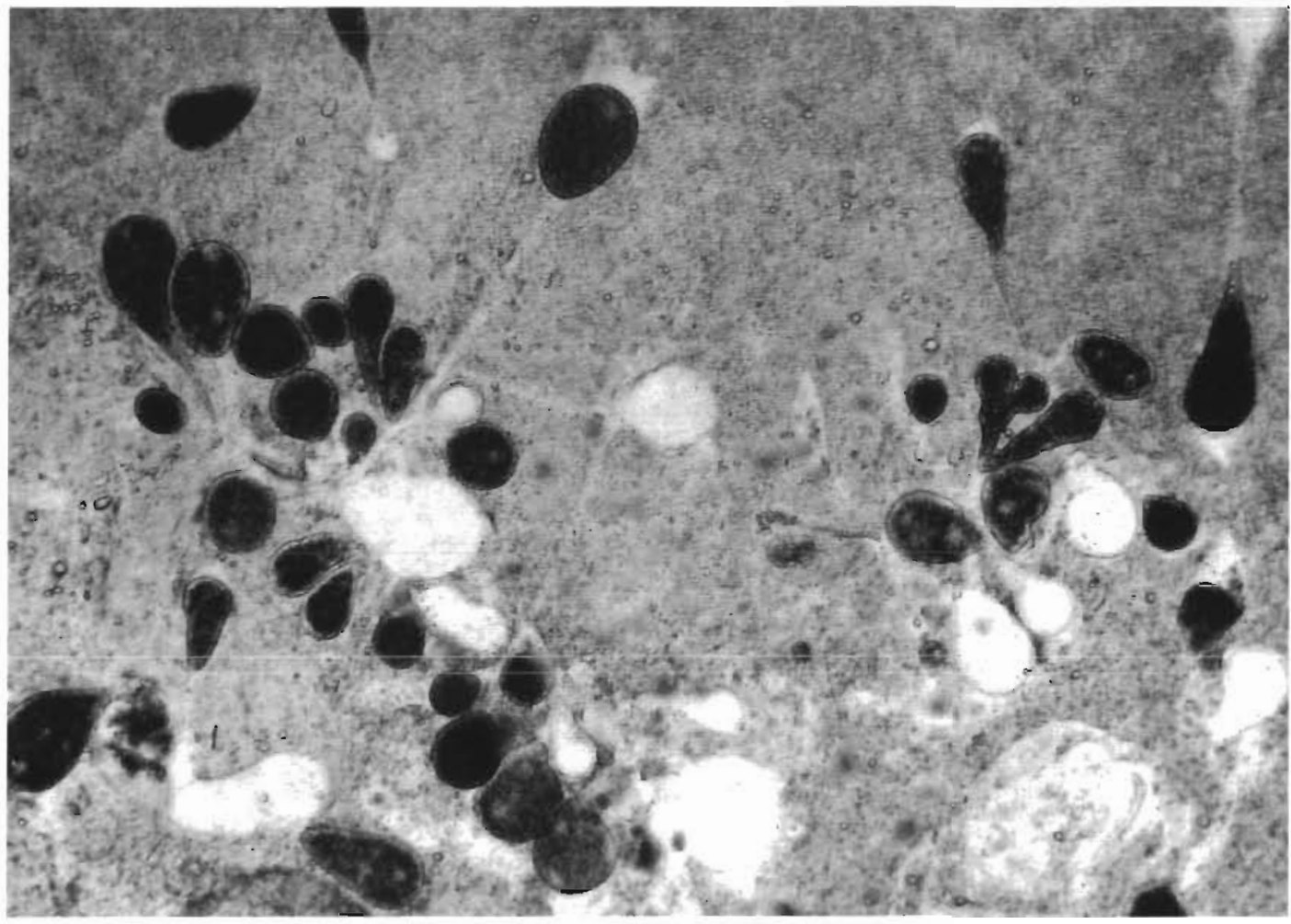

Fig. 3. Growth of pseudohypha from spores of Ichthyophonus hoferi in the heart of herring. Note the different patterns of growth

hyphae were found, while pseudohyphae were the dominating form in the infected heart tissue kept at $20^{\circ} \mathrm{C}$ for $24 \mathrm{~h}$. In the later case, pseudohyphae might have grown out of one or several spots on the wall around the spore and continued as single, double or multiple branches (Fig. 3). After 48 h, however, pseudohyphae stopped growing and formed spores again. The shape, size and pattern of growth of the pseudohyphae were similar in all infected organs of all fish species. In herring the density of spores was found to be highest in the heart and was consistently lower in the red muscle, kidney, liver, stomach, intestine, spleen, and the brain. In sprat the most common sites for $I$. hoferi in order of decreasing severity were the spleen, kidney, liver, red muscle and the heart. In flounder, the distribution of spores of $I$. hoferi in the visceral organs was more homogenous than that in either herring or sprat. In this fish, however, the occurrence of spores in the musculature was rare (Table 2).

In all infected visceral organs of flounder, particularly the haematopoietic tissues, spores were tightly packed by the host reaction and the strength of the host reaction was not reduced with the intensity of the infection.

\section{Light microscopy}

In infected fish, Ichthyophonus hoferi was found at different densities in all examined organs. In some organs, spores were limited to certain areas. In the intestine of flounder, for instance, spores were limited to the stratum granulosum, and in herring spleen with

Table 2. Occurrence and prevalence (\%) of spores of Ichthyophonus hoferi found in different organs of microscopically examined herring (randomly chosen from the samples), flounder and sprat

\begin{tabular}{|c|c|c|c|c|c|c|c|}
\hline \multirow{2}{*}{$\begin{array}{l}\text { Fish } \\
\text { species }\end{array}$} & \multirow{2}{*}{$\begin{array}{l}\text { No. examined } \\
\text { (No. infected) }\end{array}$} & \multicolumn{6}{|c|}{ No. observed (prevalence) } \\
\hline & & Heart & Liver & Spleen & Kidney & Lateral muscles & Brain \\
\hline Herring & 287 (13) & $13(4.5)$ & $9(3.1)$ & $7(2.4)$ & $9(3.1)$ & $12(4.2)$ & $4(1.4)$ \\
\hline Sprat & $77(9)$ & $2(2.6)$ & $5(6.5)$ & $6(7.8)$ & $6(7.8)$ & $3(3.9)$ & \\
\hline Flounder & $120(17)$ & $17(14,1)$ & $17(14.2)$ & $17(14.2)$ & $15(12.5)$ & $4(3.3)$ & $6(5.0)$ \\
\hline
\end{tabular}


Table 3. Statistical spore diameter data for Ichthyophonus hoferi from different organs and tissues of herring, flounder and sprat. Tot: total; He: heart; Li: liver; Sp: spleen; Ki: Kidney; Mu: muscle; Br: brain; $\bar{x}$ : mean; SD: standard deviation; Min: minimum; Max: maximum

\begin{tabular}{|c|c|c|c|c|c|c|c|c|c|c|c|c|c|c|c|c|c|c|c|}
\hline \multirow[t]{2}{*}{ Species } & \multicolumn{7}{|c|}{ Herring } & \multicolumn{6}{|c|}{ Flounder } & \multicolumn{6}{|c|}{ Sprat } \\
\hline & Tot & $\mathrm{He}$ & $\mathrm{Li}$ & $\mathrm{Sp}$ & $\mathrm{Ki}$ & $\mathrm{Mu}$ & $\mathrm{Br}$ & Tot & $\mathrm{He}$ & $\mathrm{Li}$ & $\mathrm{Sp}$ & $\mathrm{Ki}$ & $\mathrm{Mu}$ & Tot & $\mathrm{He}$ & $\mathrm{Li}$ & $\mathrm{Sp}$ & $\mathrm{Ki}$ & $\mathrm{Br}$ \\
\hline $\bar{x}$ & 45.6 & 58.1 & 35 & 45.7 & 40.2 & 54.6 & 54.6 & 51 & 50.6 & 50.5 & 53.6 & 43.5 & 51.9 & 41.7 & 67.2 & 30 & 40 & 21.7 & 30.5 \\
\hline $\mathrm{SD}$ & 27.8 & 31.1 & 15.9 & 44.5 & 23.1 & 16.9 & 16.9 & 18 & 24.8 & 15.9 & 16.5 & 16.5 & 26 & 30.3 & 32 & 8.2 & 7.1 & 12 & 6.5 \\
\hline Min & 5 & 20 & 15 & 20 & 5 & 25 & 25 & 5 & 30 & 5 & 15 & 10 & 20 & 5 & 10 & 20 & 30 & 5 & 20 \\
\hline $\operatorname{Max}$ & 230 & 180 & 75 & 230 & 120 & 80 & 80 & 120 & 110 & 85 & 95 & 80 & 120 & 120 & 120 & 40 & 50 & 65 & 45 \\
\hline
\end{tabular}

light to moderate infection spores were limited to the red pulp. In the active form of infection, the tissue of infected organs was replaced by the pathogen mass, sometimes accompanied by granulomatous elements.

Except for some differences regarding the size and host-parasite interactions, the morphology and developmental stages of IChthyophonus hoferi were similar in herring, sprat and flounder and encapsulated spores were, again, the common features of the parasite.

The diameter of the spores varied in different tissues as well as in different species and individuals of the same species (Table 3 , Fig. 4). The size of the spores in different organs of flounder was more homogeneous than in either herring or sprat, and in sprat and herring the spore size patterns were similar (Fig. 4). The largest spore was found in the spleen of a herring and measured $230 \mu \mathrm{m}$ in diameter. The smallest spores, $<5 \mu \mathrm{m}$ in diameter, were found in the red muscle of herring, flounder liver and sprat kidney (Table 3). The mean diameter of spores in flounder was significantly larger than in both herring and sprat (Table 4).

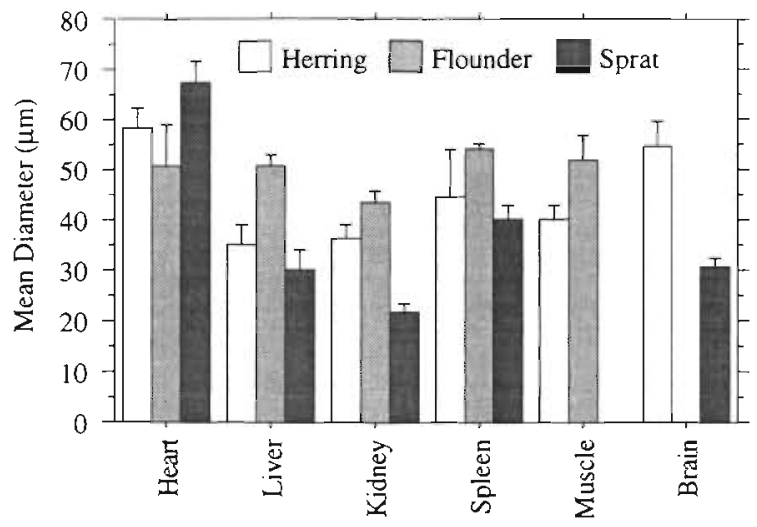

Fig. 4. Mean and standard deviation of Ichthyophonus hoferi spore diameter in different organs of 3 fish species
A distinct and easily observed host reaction to spores of Ichthyophonus hoferi was granulomatous, which was observed in almost all infected specimens. In the sectioned material, the beginning of cell infiltration around the spores was rarely observed. However, 3 distinguishable phases of granulomatous reactions, gradually leading to the final step of encapsulation of the spore in a necrotised layer, were identified. These phases were more or less identical in the different fish species, but with different intensity of the engaged cells. The 3 observed phases are as follows: (1) a relatively thick capsule surrounding the spore containing a fibrocytic layer, a 'cellular layer' mainly constructed from plasma cells and occasionally macrophages, and a necrotic inner layer created by degeneration of the median cellular layer (Fig. 5); (2) a granuloma which has the same layers as in phase 1 but with different relative thickness. The outer layer consists of the same elements as those in phase 1 but the thickness of the median or cellular layer is thinner and contains some dead cell remains, and the inner layer is thicker than that found in phase 1. (3) In the third phase the diameter of the whole granulomatous decreases, the thickness of the outer layer remains unchanged while that of the median is thinner compared with corresponding layers in phases 1 and 2 and it is filled with cell remains, i.e. necrosis, with only a few living cells 


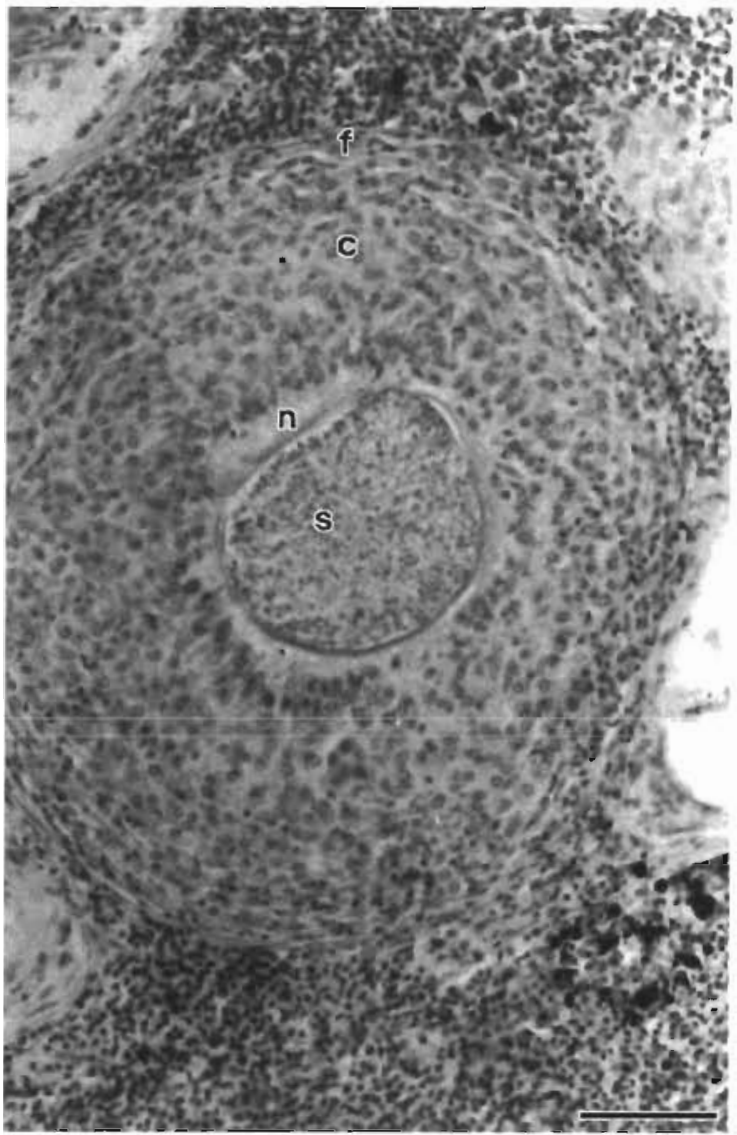

Fig. 5. The passive spore of Ichthyophonus hoferi (s) surrounded by the granuloma, phase 1 . f: Fibrocytic layer; $c$ : cellular layer; n: necrotic layer. H\&E, flounder, spleen. Scale bar $=50 \mu \mathrm{m}$

and, finally, the thickness of the third layer has increased (Fig. 6). In some cases, especially in flounder, extensive granulomatas were seen enclosing several generations of spores of different sizes. In infections involving many spores, the whole spore aggregate, as well as each of the spores, was surrounded by a layer of fibrocytes or a fibrotic capsule of variable thickness. In herring and sprat most spores were found singly packed in a capsule, while in flounder the common feature was 1 capsule containing from a few to several encapsulated spores. Some cells in the granuloma showed signs of degeneration. Hydropic or vacuolar degeneration and pyknosis were frequently observed in the haematopoietic tissues (Figs. 6 \& 7).

In herring and sprat the encapsulation and/or necrotic layer around the spores was thinner than that in flounder. In the formes species the granulomatous reaction was either weak or absent in fish in the active phase of infection in comparison with those in the passive phase. In flounder, however, no reduction in host reactions in the active phase of infection was observed, i.e.

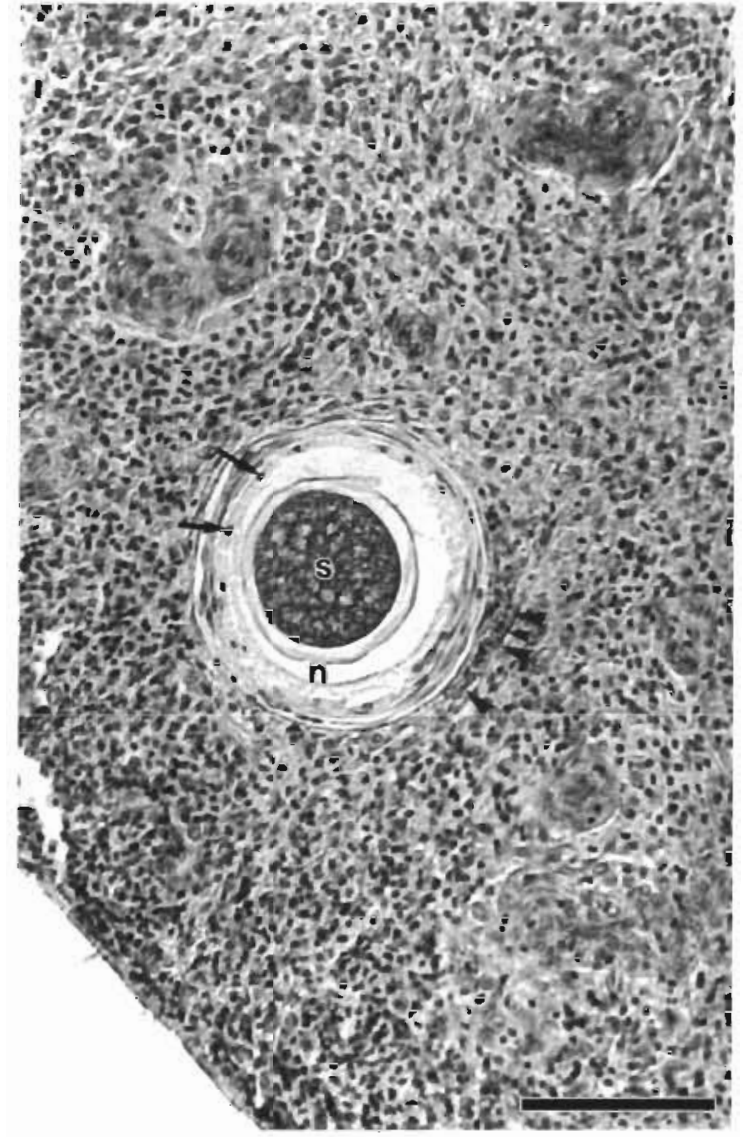

Fig. 6. Spore of Ichthyophonus hoferi (s) encapsulated in the last phase of the granulomatous process, i.e. phase 3 . Arrows: pyknosis degeneration of host cells; arrowheads melanomacrophages; $n$ : necrotic layer. H\&E, herring, spleen. Scale bar $=100 \mu \mathrm{m}$

numerous small spores and/or spores forming pseudohyphae surrounded by host reaction were present. Associated with granuloma, especially in the haematopoietic tissues, were melanomacrophages. Deep-brown pigmented melanomacrophage centres were most conspicuous in the infected flounder spleen (Fig. 8), although these, to a lesser extent, were also observed in uninfected flounder. In the herring spleen, however, this structure was rarely seen and instead infiltration of golden-yellow pigmented macrophages around the spores was the dominant form (Fig. 6). The same kind of cells was also seen in the vicinity of the spores in the liver of all infected species. In the microscopical examination of herring obtained from commercial catches off Norwegian coasts, which showed black spots in their flesh, encapsulated spores of Ichthyophonus hoferi were found to be surrounded by deposited melanin. Such a melanin reaction was not found in herring caught along the Swedish coasts. However, no melanocytes were found in connection with the melanin or in the vicinity of the spores. 


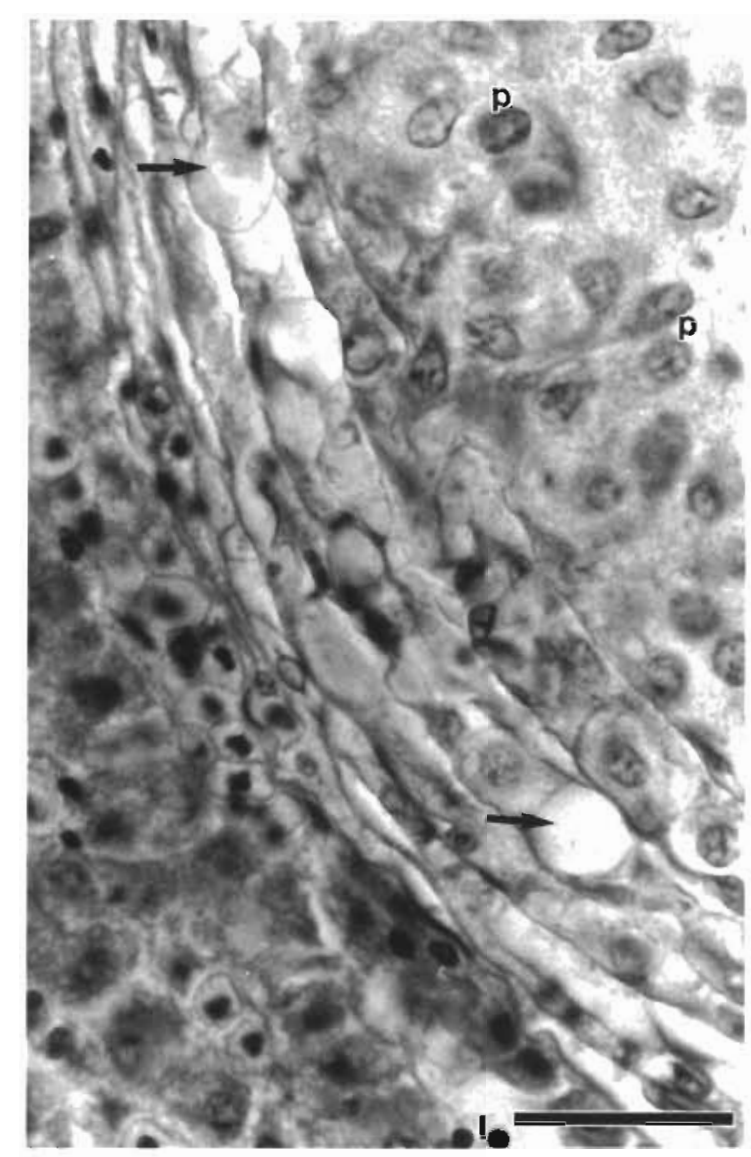

Fig. 7. Outer most part of a granuloma. Arrows: hydropic degeneration; l: lymphocytes; p: plasma cells. H\&E, flounder, liver. Scale bar $=20 \mu \mathrm{m}$

In spite of extensive host reaction around the spores only a few degenerated spores or granuloma with no remaining trace of spore were observed. Thus, dead spores were found only in the intestinal wall and in the spleen of sprat and flounder. Degeneration was indicated by loss of integrity of the spore wall as well as by contraction, vacuolation and fragmentation of the cytoplasm (Fig. 9). Other spores, regardless of how extensive the host reaction was, seemed to be able to grow and to form pseudohyphae. The pseudohyphal bodies could emerge from 1, 2, or several spots of the capsule. The pseudohyphae in material fixed after fish death were narrower than the material fixed several hours after death. They usually emerged from 1 and rarely from 2 spots on the spores while those samples fixed several hours post-mortem had pseudohypha emerging from 1 or several spots on the spore. In freshly fixed material the pseudohyphae were observed measuring in length up to 4 times the spore diameter. In the tip and wall area of active spore cytoplasm (Fig. 10) as well as the pseudohyphae (Fig. 11) dense basophilic granular bodies were seen.

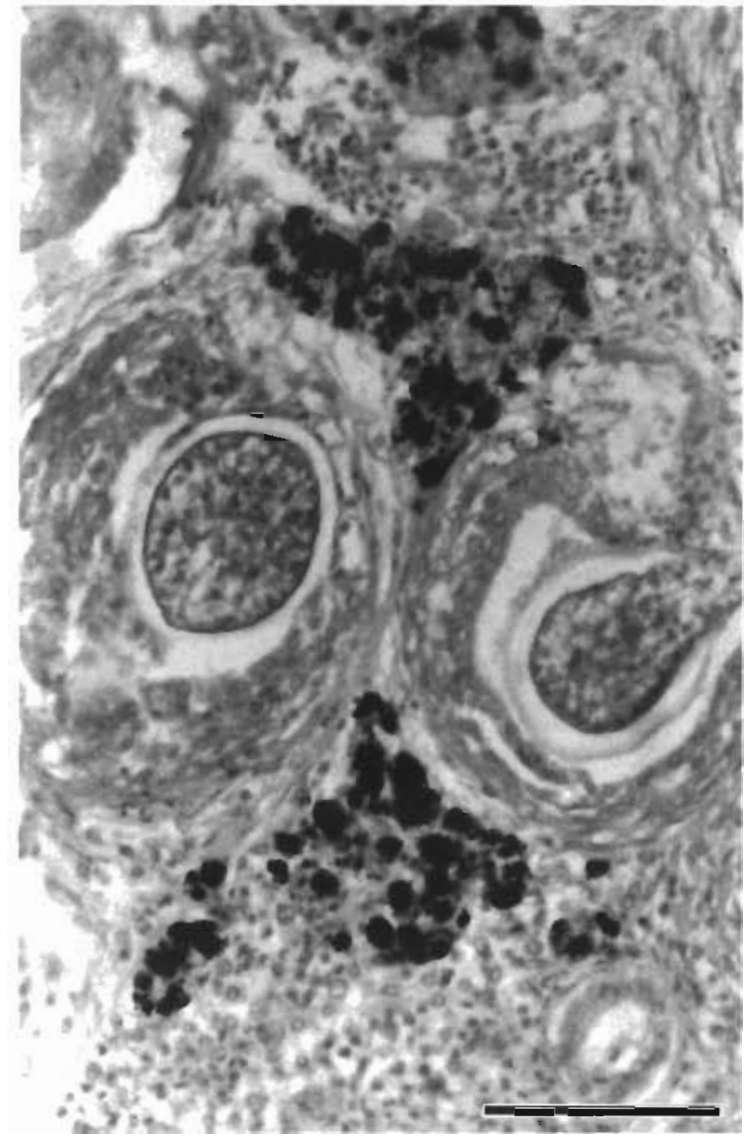

Fig. 8. Black melanomacrophage centres in close association with Ichthyophonus hoferi. H\&E, flounder, spleen. Scale bar $=50 \mu \mathrm{m}$

Spores of Ichthyophonus hoferi were PAS positive The strongest reaction was toward the bilaminated wall of the spores, the inner one of which expands together with the pseudohypha as it grows. Furthermore, positive reactions in a patchy distribution were seen within the spores as well as in and around the capsule, an indication of melanomacrophages (Fig. 12). The spores showed a multinucleated cytoplasm in which the nuclei were usually distributed without a definite arrangement (Figs. 5 \& 9). In some spores, i.e. spores in the active form, and in pseudohyphae, the nuclei were mostly peripheral (Figs. 10 $\& 11$ ). The nuclei numbered from only a few in sections of the smallest spores to several hundred in the larger spores. Each nucleus had 1 basophilic nucleolus located centrally, or slightly acentric, surrounded by a zone of less basophilic nucleoplasm which was surrounded by a thin, deeply basophilic nucleo-membrane. In some spores, i.e. 'plasmodio-spores', the cytoplasm was cleft into units containing from 1 to a few nuclei accompanied by cytoplasmic material (Fig. 13). Each unit, i.e. plasmodium, had a very thin membrane 


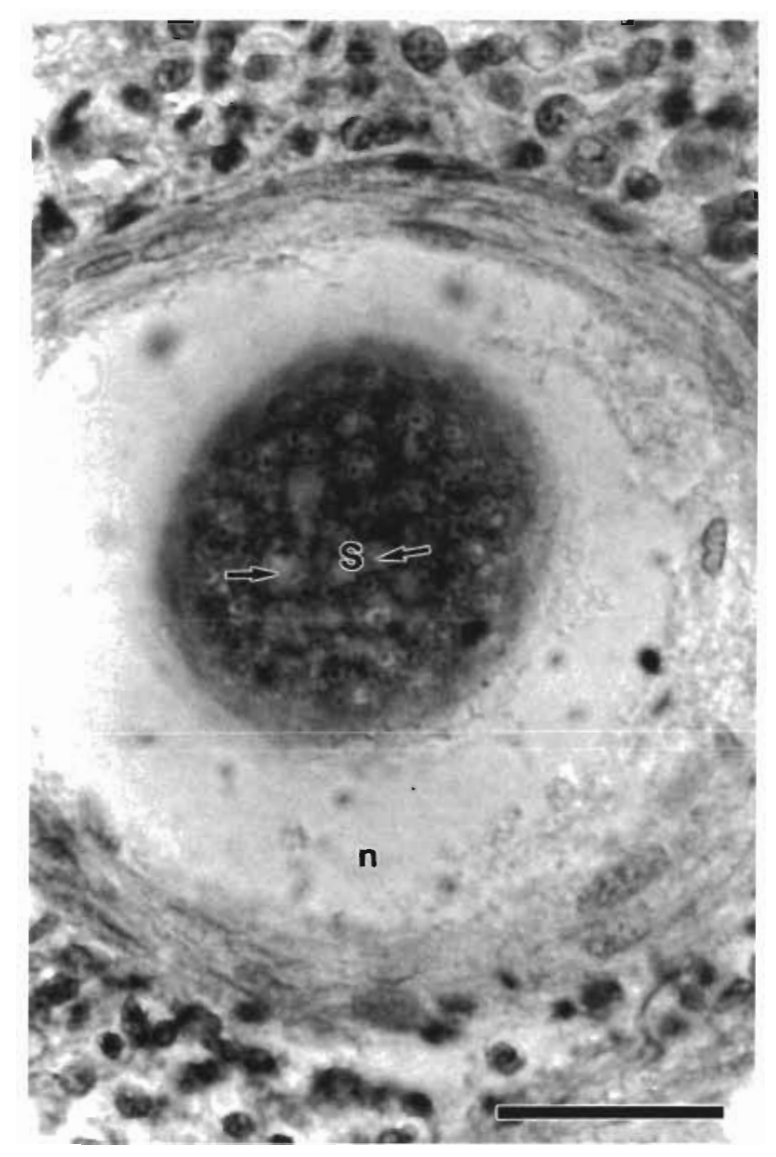

Fig. 9. Early stage of degeneration of passive spore of Ichthyophonus hoferi (s). Note the nuclei distribution, vacuolation of the cytoplasm (arrows), thickness of the necrotic layer (n) and absence of any live host cell in the capsule, an indication of the relative age of the spore. H\&E, herring, kidney. Scale bar $=20 \mu \mathrm{m}$

and some of these developed pseudopodia. Plasmodia were also seen free in the inter-cellular space of different organs (Fig. 14), either with or without pseudohyphae.

\section{Transmission electron microscopy}

Different types of host cells were observed in the capsule around the spores of Ichthyophonus hoferi. The occurrence and composition of these cells varied in different hosts, in different organs as well as around spores of different phases. The dominant cell types surrounding spores were fibroblasts, fibrocytes and plasma cells. Fibrocytes were arranged in a multi-layer ring and were in desmosome junction with each other. Following this layer were fibrous and necrotic layers, the latter in direct contact with the spore (Fig. 15). Around some spores and pseudohyphae, macrophages and lymphocytes were seen to be in direct contact with

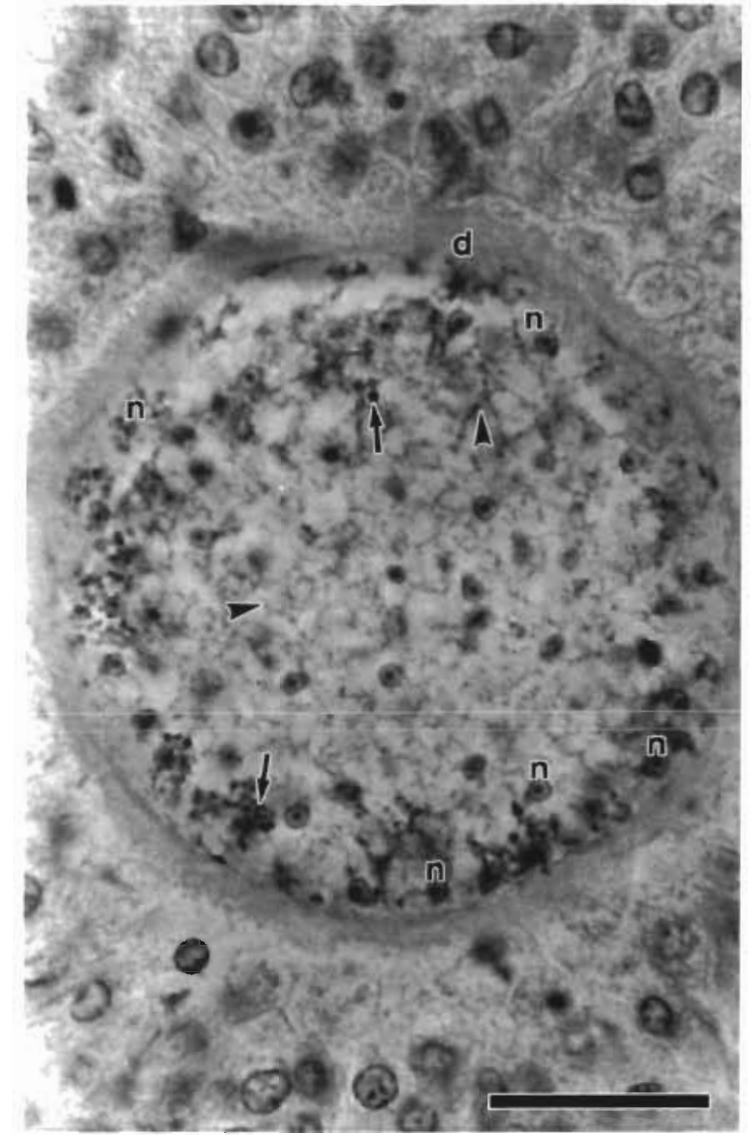

Fig. 10. Multi-nucleated active spore of Ichthyophonus hofen surrounded by relatively thin necrotic deposits (d). Ground cytoplasm with dense granular bodies (arrows), containing a network of fibre-like cords (arrowheads); n: peripheral nuclei Scale bar $=20 \mu \mathrm{m}$

the pathogen, depositing some material on the outer most part of the spores.

The wall around the spore was composed of 1 to 7 layers. In multi-layer walls, 2.2 to $2.9 \mu \mathrm{m}$ thick, up to 7 heterogeneous, electron-lucent and electron-dense layers of different thickness, ranging from 0.1 to $1.2 \mu \mathrm{m}$, were arranged alternatively. The uni-layer, 4.6 to $5.3 \mu \mathrm{m}$ thick, wall around the spore was composed of circumferentially aligned heterogeneous microfibrils The inner part of the wall was in direct contact with an undulant plasmalemma (Fig. 16). The heterogeneous multinucleated cytoplasm was surrounded by an electron-dense plasmalemma. The immediate zone under the plasmalemma was a cytosol with a thin $(0.1$ to $0.7 \mu \mathrm{m}$ ) paramural endoplasm (Fig. 16).

Nuclei were spherical to slightly oval in shape, with diameters of 1.9 to $3.0 \mu \mathrm{m}$ and randomly distributed in the cytoplasm of spores in the passive phase (Fig. 16). The nuclei usually occurred singly but occasionally in groups of 2 to 4 (Fig. 17), some having their bilami- 
Fig. 11. Tip of a pseudohypha. Note dense granular bodies (arrowheads) and the dominant peripheral distribution of nuclei (arrows). Scale bar $=15 \mu \mathrm{m}$

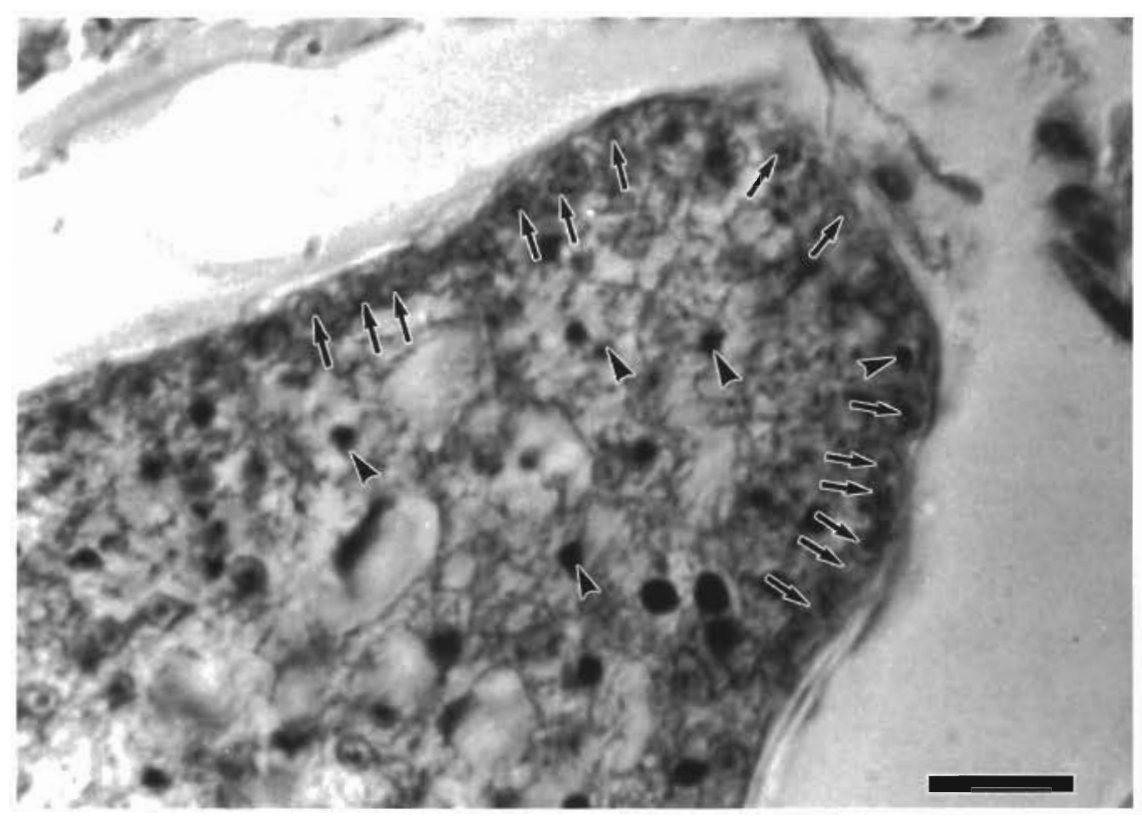

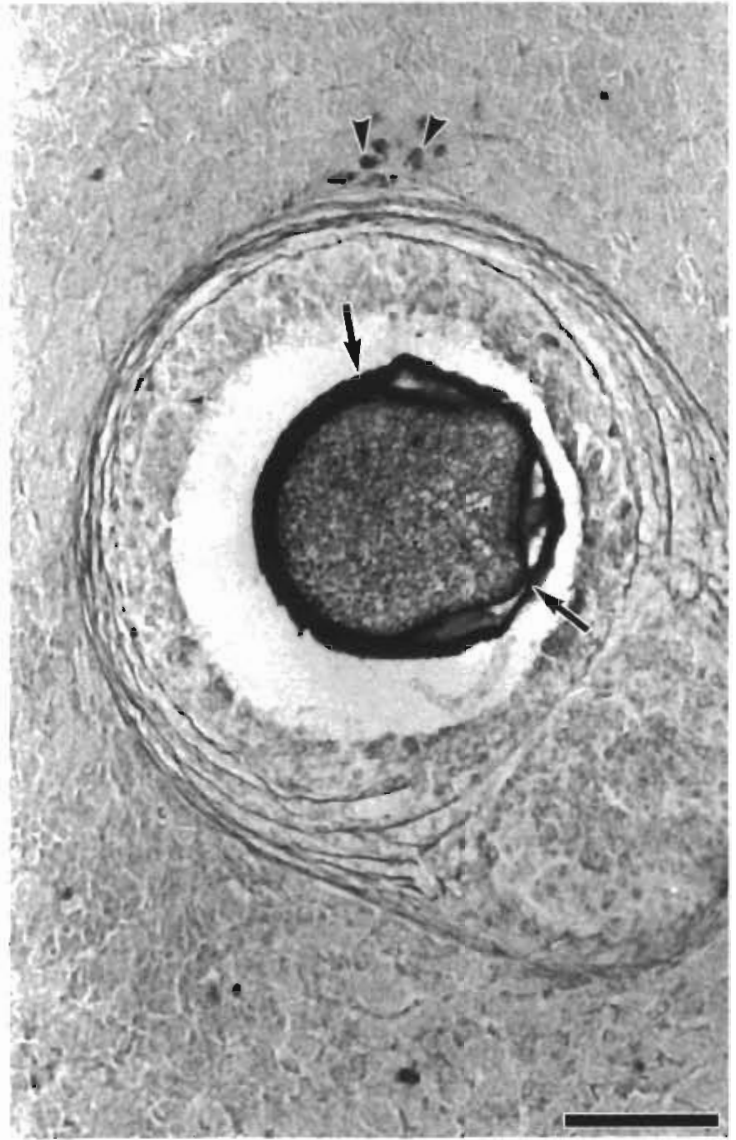

Fig. 12. Strong PAS reaction towards the bilaminated wall around the developing spore of Ichthyophonus hoferi, the extension of the inner section as pseudohypha growth (arrows) and patchy distribution of reaction inside the spore. Melanomacrophages (arrowheads) applied to the fibrocytic capsule. PAS, herring, heart. Scale bar $=100 \mu \mathrm{m}$

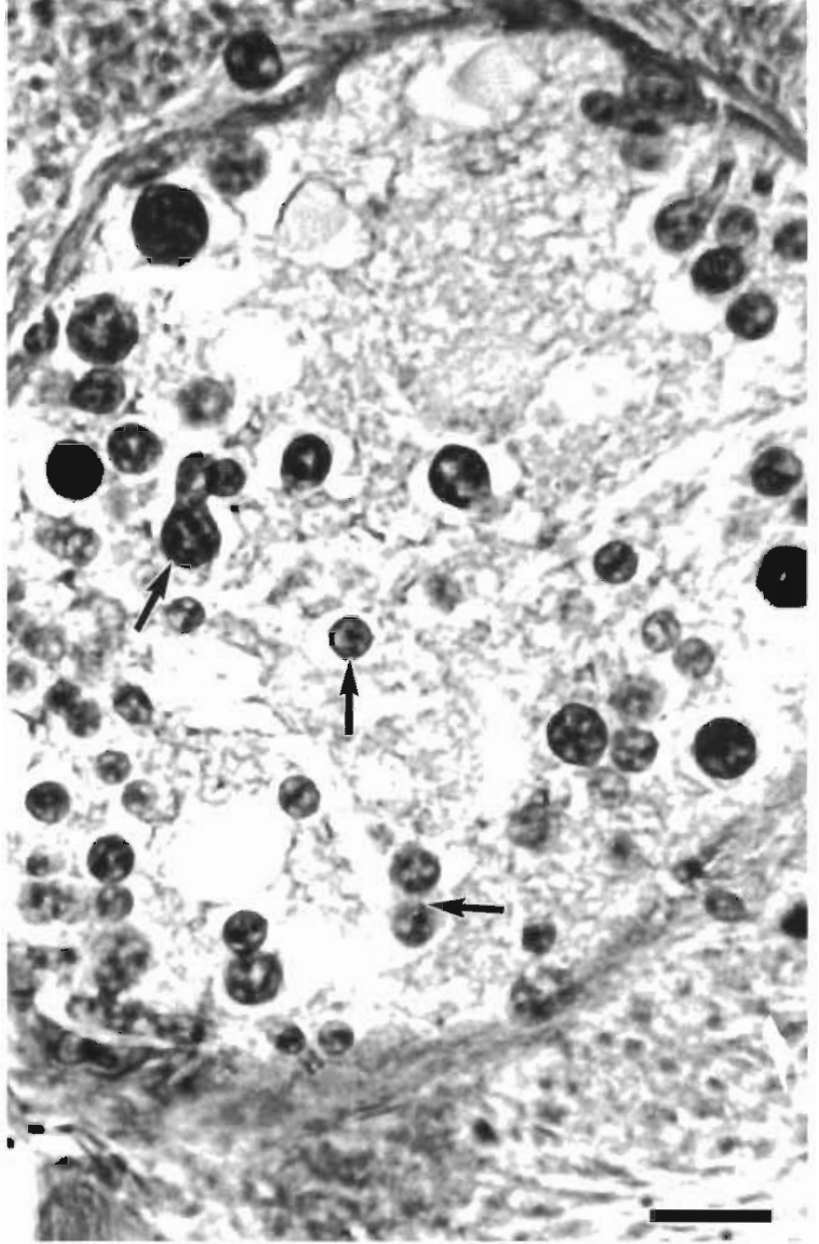

Fig. 13. Plasmodia (arrows) formation within the plasmodiospore of Ichthyophonus hoferi. H\&E, herring, heart. Scale bar $=25 \mu \mathrm{m}$ 


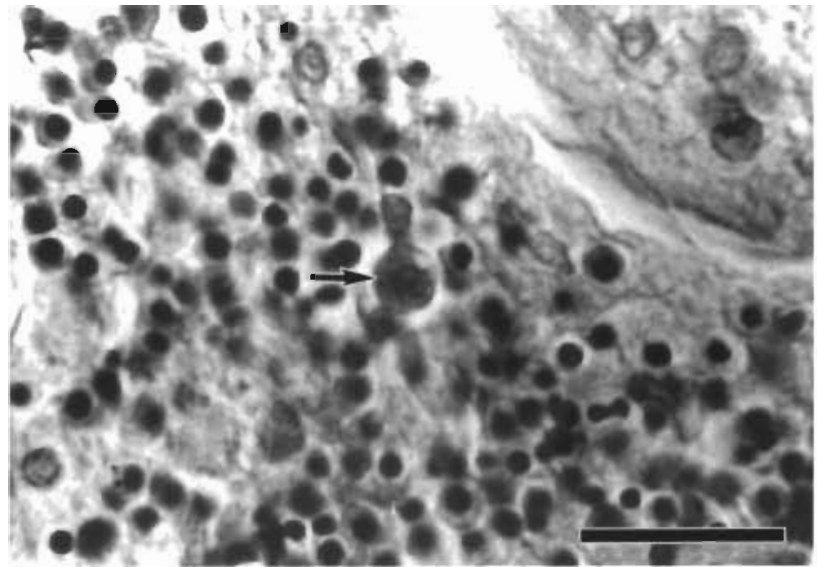

Fig. 14. Mono-nucleated plasmodia (arrow) of Ichthyophonus hoferi in the spleen of herring. Scale bar $=25 \mu \mathrm{m}$

nated membrane in close contact with the endoplasmic reticulum (ER). Some nuclei were also found to be connected to the plasmalemma through their ER. Nucleoli were 1.1 to $1.5 \mu \mathrm{m}$ in diameter and were centric or slightly acentric in the granular nucleoplasm. In the nucleoli the spherical pars fibrosa usually occurred acentric in and was enclosed by the pars granulosa. Another kind of arrangement was found where the pars fibrosa was distributed in a patchy arrangement in the pars granulosa (Fig. 17).

In spores and pseudohyphae spherical mitochondria (0.60 to $0.79 \mu \mathrm{m}$ in diameter) had a bilaminated membrane $(0.019$ to $0.038 \mu \mathrm{m})$ and tubulo-vesicular short cristae with a diameter of 0.056 to $0.113 \mu \mathrm{m}$ (Fig. 18).

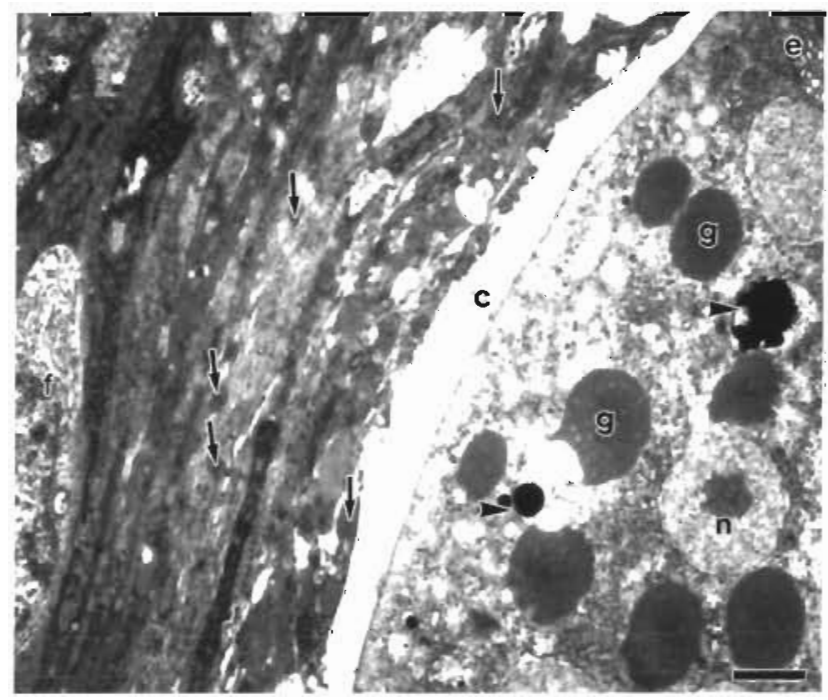

Fig. 15. Spore of Ichthyophonus hoferi in the necrotic capsule (c) surrounded by fibrotic cells that form desmosome junctions with one another (arrows). e: endoplasmic reticulum; f: fibroblast; g: glycogen bodies; n nuclei; arrowheads: lipid droplets. Scale bar $=1.1 \mu \mathrm{m}$

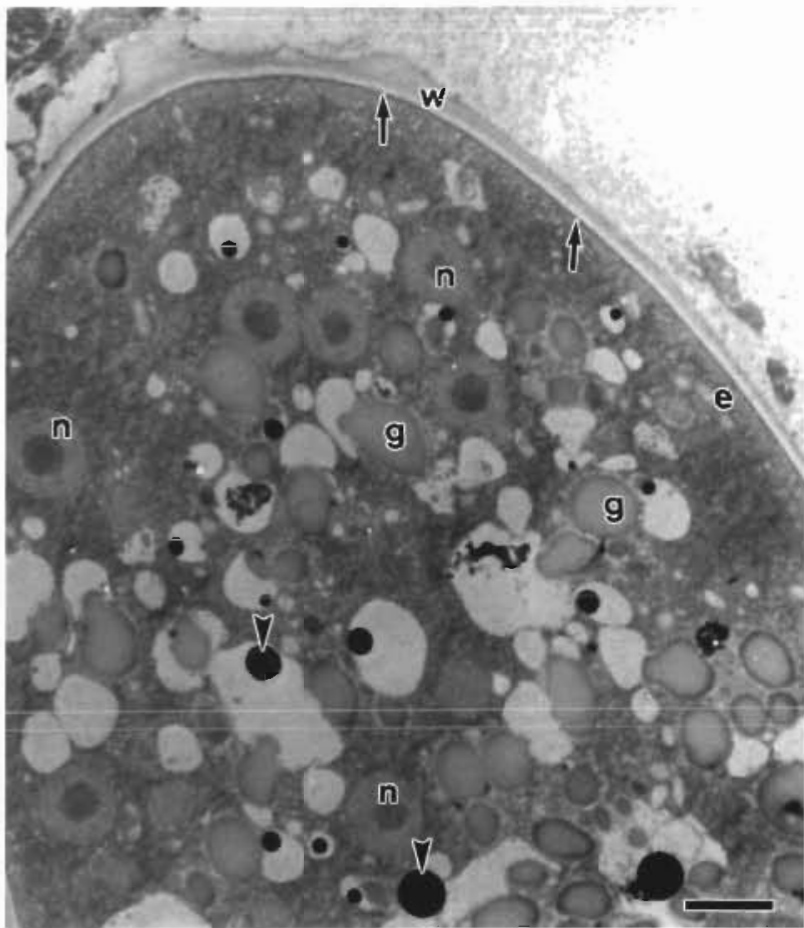

Fig. 16. Overview of part of a passive spore of Ichthyophonus hoferi. e: paramural endoplasm; g: glycogen bodies $\mathrm{n}$ : nuclei; $\mathrm{w}$ : necrosis; (arrows) undulant plasmalemma arrowheads: lipid droplets. Scale bar $=0.47 \mu \mathrm{m}$

Single dictyosomes were common and located close to the nuclei. They consisted of plate-like 0.011 to $0.023 \mu \mathrm{m}$ cristernae (Fig. 19). Both rough and smooth endoplasmic reticulum (RER and SER) (Fig. 15) as well

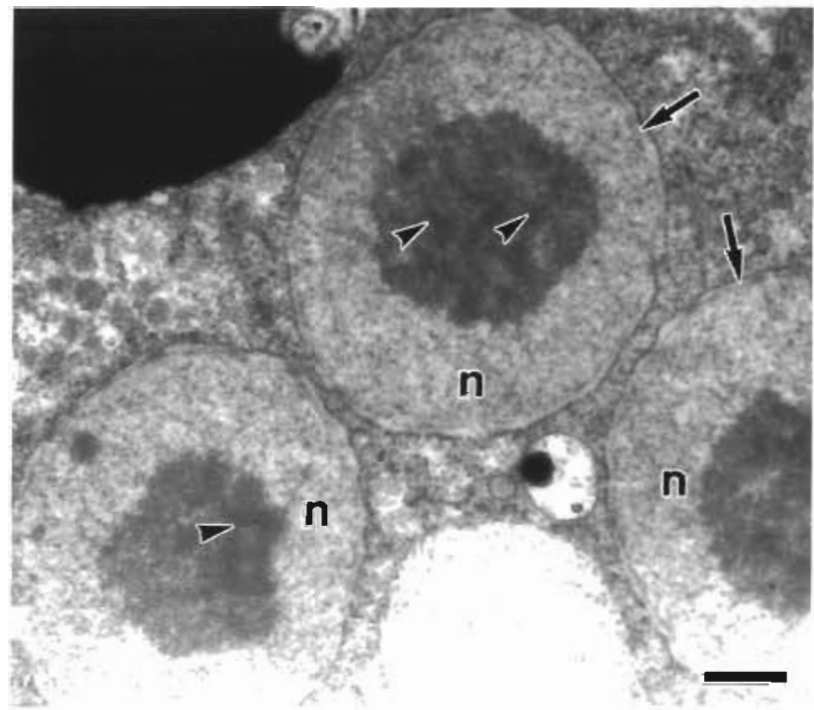

Fig. 17. Three nuclei (n) of Ichthyophonus hoferi. Note the patchy distribution of pars fibrosa (arrowheads) in the pars granulosa. Scale bar $=0.6 \mu \mathrm{m}$ 


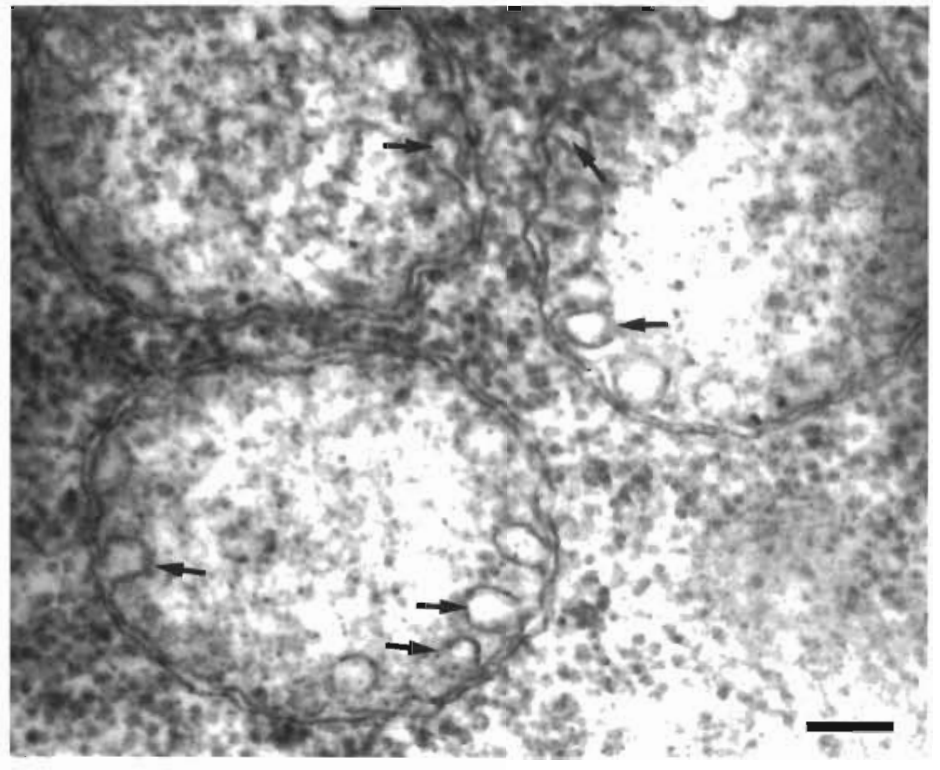

Fig. 18. Three mitochondria of Ichthyophonus hoferi. Note the short tubo-vesicular cristae (arrows). Scale bar $=0.15 \mu \mathrm{m}$

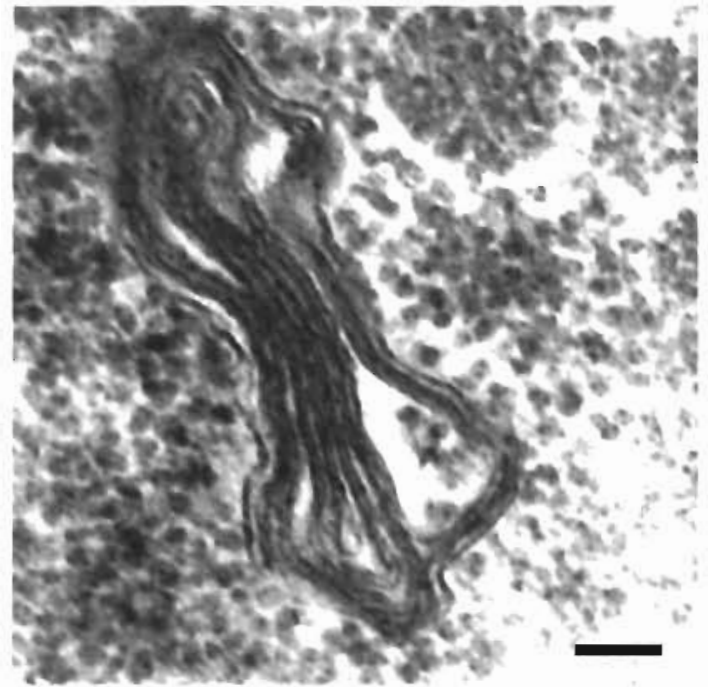

Fig. 19. A single dictyosome of Ichthyophonus hoferi with plate-like cristernae. Scale bar $=0.9 \mu \mathrm{m}$ as single ribosomes and polysomes were seen in the cytoplasm. The cytoplasm also contained electron-dense lipid droplets, relatively big electronlucid vacuoles of glycogen storage (Figs. 15 \& 16), lysosomes, and microtubular and multi-vesicular bodies. Glycogen vacuoles were relatively abundant in spores in the passive form compared to those in the active form. Multi-vesicular bodies were structures with bilaminated round membrane enclosing micro-vessels.

In the pseudohyphae and spores in the active phase, both RER, SER, mitochondriae and dictyosomes were well developed around the nuclei (Fig. 20). Furthermore, enormous numbers of lysosomes heading towards the plasmalemma of pseudohyphae were common.

\section{DISCUSSION}

In this study 9 species of fishes were screened of which 3 were found to be infected with Ichthyophonus hoferi. The absence of infection in these species is probably due to the low number of specimens examined.

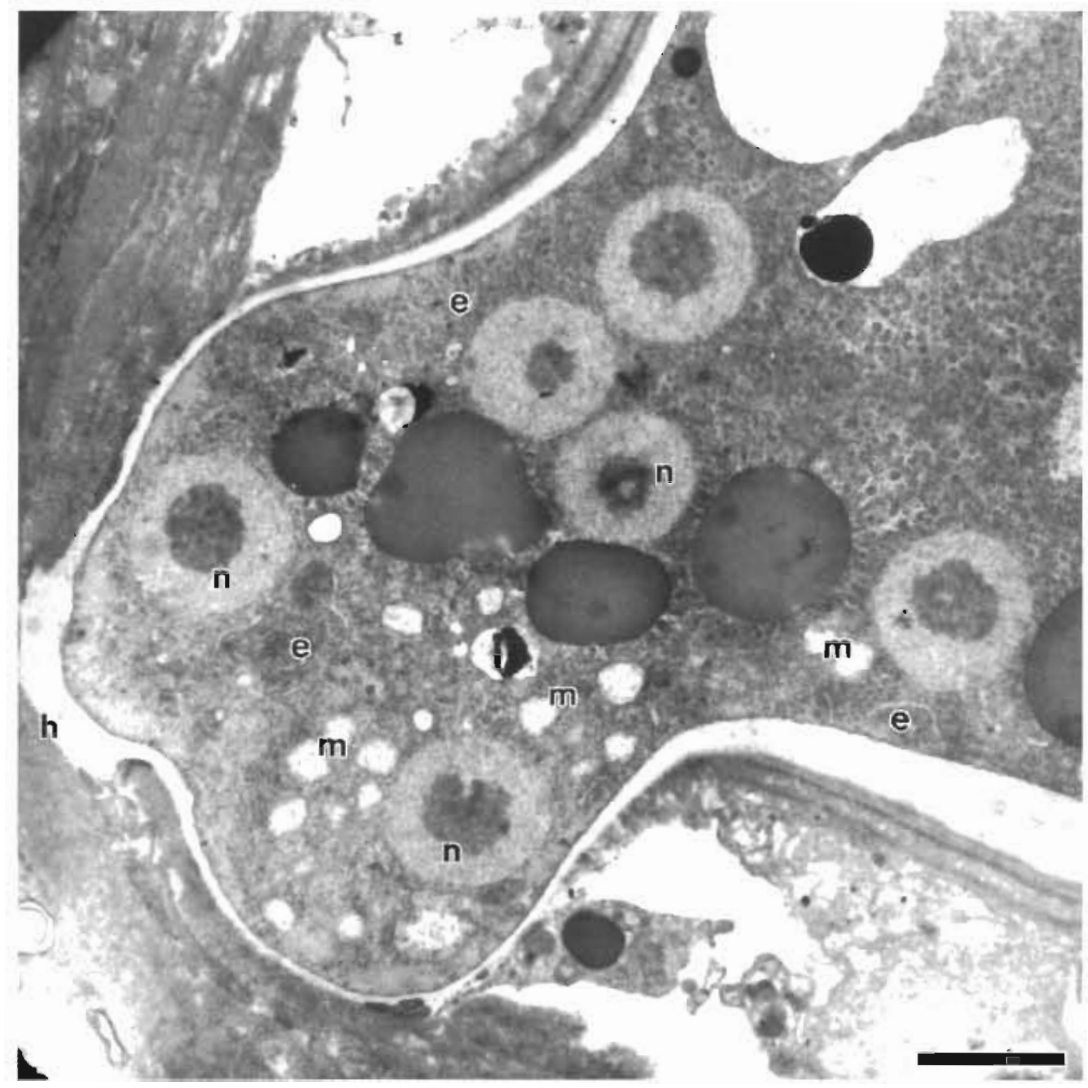

Fig. 20. Pseudohyphae of Ichthyophonus hoferi penetrating and lysing the host tissue (h) by means of lytic activities. Note the well-developed endoplasmic reticulum (e), mitochondria (m); also note flow of nuclei $(\mathrm{n})$ and other cytoplasmic material in the newly formed pseudohyphae. Scale bar $=2.5 \mu \mathrm{m}$ 
Herring is a commonly infected host in the western North Atlantic (Sindermann 1990) and has now become a common host also in the eastern North Atlantic and adjacent waters (Patterson 1996, Rahimian \& Thulin 1996).

The microscopical structures of the passive form of the spore, pseudohyphal body, host reaction, as well as the fine structure of the parasite from herring, sprat and flounder as found in this work conform closely to the descriptions of spore, 'hyphae' and host reaction in the same or in other host species world-wide (Alderman 1982, McVicar 1982, Okamoto et al. 1985, Paperna 1986, Rand 1990, Sindermann 1990). The present work, however, contains previously undescribed structures that will be discussed. The pathologic, gross and microscopic signs of Ichthyophonus hoferi in herring, sprat and flounder from the Skagerrak-Kattegat were only slightly different from previous reports of $I$. hoferi in the same or in different host species. Nevertheless, inter- and intra-specific differences exist, such as differences in nodule appearance, the main infected organs and presence of melanomacrophages. Furthermore, the descriptions of host-parasite interaction and the fine structure of $I$. hoferi provided in this work add to our knowledge of the morphology and biology of this organism.

Ichthyophonus hoferi occurred frequently in the tissues of infected fish as a spherical, thick-walled and multinucleated cell. This cell has been named the following: multinucleated cyst, spherical multinucleated cyst (Daniel 1933a, b)i parasite 'resting spore' cyst (Fish 1934); resting spore (Sporston 1944); spore, quiescent spore (Sindermann \& Scattergood 1954); cyst, latent cyst (Dorier \& Degrange 1961); multinucleated spherical bodies (Miyazaki \& Kubota 1977); M-spore (Paperna 1986); resting spore, sporangia, resting sporangia, spore and intercalary spore (Rand 1990). The name frequently used for the developing form of I. hoferi, i.e. threadlike extension of the cytoplasm and plasmalemma, is hypha. However, in the present study, considering the new findings regarding the taxonomic position of $I$. hoferi and the author's observations of naturally infected fish, the name 'pseudohypha' is used. The pseudohypha, at least, in the 'plasmodia' of $I$. hoferi is considered a locomotive apparatus which acts like a 'pseudopodium'. In more mature stages the pseudohypha are apparently used either simply for translocation, or for distribution of the organism from the original, capsulated, location of the parasite. This formation has been reported as producing plasmodia (Dorier \& Degrane 1961) and, since it also been used as a locomotive apparatus, the name 'pseudohypha' seems to be justified. McVicar (1982) has stated that the formation of the 'hypha' is a postmortem event. Sproston (1944), however, found an extensive host reaction around the 'hypha' of $I$. hoferi, pointing to the pre-mortem nature of the pseudohypha formation. Observations such as those reported here indicate that there are 2 kinds of pseudohypha, premortem and post-mortem types. The pre-mortem type is limited to 1 or 2 branches originated from the spore. These branches are relatively thin and long and do not bifurcate. The post-mortem type are thick and bifurcate shortly after their origin. The pseudohyphal growth seems to progress using enzymatic activity. Spanggaard (1993) identified 7 active enzymes in crushed pseudohyphae. The present study showed that the pseudohyphae usually grew up to 4 times longer than the diameter of the spore and had highly basophilic vacuoles, possibly containing different enzymes. Furthermore, the PAS positive reaction inside the $I$. hoferi appears to be evidence of vacuoles storing polysaccharides.

The present results show the undeveloped spores (i.e. spores in passive phase) of Ichthyophonus hoferi in the host. This form can be recognized by the presence of an extensive granulomatous reaction and/or heavy encapsulation of the spore due to the long quiescence in spore growth and/or development in this form, as well as by the random distribution of the nuclei in the cytoplasm. The developing spore (i.e. spore in active phase), in which the spore undergoes different developmental forms and grows rapidly, lacks the surrounding granulomata elements and/or capsule because of the speed of growth. In this form the nuclei are peripherally scattered in the spore, and the endoplasmic reticulum is abundant and well developed. It may produce pseudohyphae, or may form another kind of spore, the 'plasmodio-spore', which contains from only a few to many 'plasmodia'. Plasmodia seem able to reinitiate what is termed an 'endogenous' or 'secondary' cycle in the host, and has from 1 to 4 nuclei and may further develop a 'developing spore', or may cease growth and become an 'undeveloped spore'.

A range of spore sizes have been reported (Machado-Cruze et al. 1982, Rand 1990, Sitja-Bobadilla \& Alvarez-Pellitero 1990) but in most records it is not clear whether the wall was included or not; it therefore has been assumed that the reported spore sizes include the wall. Comparison between spore size from herring from the eastern and western North Atlantic show that spores from the Skagerrak-Kattegat are bigger than those from the western north Atlantic, as are the spores of flounder from this study and yellowtail flounder (Rand 1990). These differences may be due to variation in the extent of the host reaction or in the developmental stage of the parasite. The formation of the wall around the spore is probably a product of host and pathogen interaction and this wall is the main restric- 
tive factor limiting spore size. The extent of the wall around the spore is considered to be one of the factors triggering the formation of the pseudohypha from the spores already overloaded with cytoplasmic material. The present study describes the contribution of different host cells to the construction of the spore wall. Furthermore, the morphology of the spore wall varies in different host species as well as in different organs (author's pers. obs.) Studies of the chemical composition of the wall show that these components varied amongst the spores from different specimens examined by Bartnicki-Garcia (1968) and Rand (1990). This also suggests that the spore wall of Ichthyophonus hoferi is not a reliable source for phylogenic information.

The heart was the main site of infection in herring and flounder while the spleen was the main infected organ in sprat. In herring, the lateral muscles (red muscles) have the same level of susceptibility as the heart. Sindermann \& Scattergood (1954) speculated that both tissues have a rich blood supply. In flounder, however, lateral muscles show the lowest susceptibility to Ichthyophonus hoferi. This may be due to the absence of a red muscle system in the lateral muscles of flatfishes, which thus contain relatively fewer blood vessels and consequently fewer plasmodia. However, this contradicts the finding that the heart and red musculature system in sprat had the lowest susceptibility to the infection, even though these organs had a rich source of blood vessels. From the present work and that reported from the same or other host species (Sindermann \& Scattergood 1954, Paperna 1986), it is apparent that the dispersal of spores varies in different hosts. In the advanced phase of the disease, however, any organ could be involved, regardless of the species.

Except in 2 herring, no external gross clinical signs were observed. This contrasts with reports of ichthyophonosis in herring from the western North Atlantic (Sindermann \& Scattergood 1954). The difference between infected herring, sprat and flounder in our study and herring from other studies may be explained by inter-specific population differences in the immune system or by differences in the developmental stage of the parasite. Hodneland et al. (1997) also reported widespread 'sandpaper' and pigmentation in infected herring off the Norwegian coasts. An explanation for the presence of this common effect in both the Gulf of St. Lawrence and along the Norwegian west coast and its absence in the Skagerrak-Kattegat may be that the parasite in herring in the Norwegian Deeps, for unknown reasons (e.g. extreme differences of water temperature), develops more rapidly and is distributed faster in the host. Alternatively, herring in the Skagerrak-Kattegat may be more susceptible to the pathogen and die before the appearance of the final phases of infection, or the herring in this area were in the middle phase of infection and only show the last phase when they reach their summer feeding grounds, i.e. the Norwegian Deeps.

Inflammation appears to start with invasion of macrophages into the newly infected organ. These parasiteloaded areas then become centres of granulomata, as reticuloendothelial cells and fibroblasts surround the foci. In affected organs, recurrent episodes of necrosis with accompanying proliferative inflammation occur until the normal tissue is replaced by granulomatous and fibrous elements. This replacement is one of the characteristics of Ichthyophonus hoferi infection. These findings are in agreement with Bendele \& Klontz (1975). The host reaction is intensive when 2 or more spores are packed in a single granulomatous reaction. Granulomas containing several to many spores were composed of compressed epithelioid and fibrotic capsules around both the spores and the necrotic cellular debris. This type of granuloma was identified by Agius (1978) in a deep sea scabbard fish infected with an Ichthyophonus-like organism and in yellowtail flounder infected by I. hoferi (Rand 1990). These granulomas are more frequent in flounder than in herring and sprat. A frequently reported host cell around the spore of $I$. hoferi in the same or different fish species is termed a 'giant cell' (McVicar \& McLay 1985, Rand 1990). However, no such cell was found in the material studied in the present work, which again points to inter-and intraspecific differences in response to the same parasite.

In contrast to the herring sampled along the Swedish west coast some herring samples from Norway showed melanization around the spores. This type of reaction has also been reported by Sindermann \& Scattergood (1954) in herring from the western North Atlantic and from the Norwegian coasts (Hodneland et al. 1997). Microscopic examination of H\&E stained samples showed melanin pigments distributed around spores but no melanocytes were recorded. In muscle as well as in other organs of infected specimens, however, the patchy distribution of elements of a PAS-positive reaction may point to the presence of macrophages containing unsulfated polysaccharides. The role of macrophages or migrating melanocytes at these sites is uncertain, although both macrophages and melanocytes have been proposed as being melanin depositors (Roberts 1975). The function of melanin-coating macrophages is unknown. An active role, however, is proposed for melanin as part of a defence mechanism since it can be coupled with peroxide-mediated bacterial systems or can help modulate such a system by absorbing free radicals, thus reducing host tissue damage (Edelstein 1971). This could be the case in the present study, since the infected fish which developed melanincoated spores retained their texture and did not have the characteristic off-odour of ichthyophonosis. 
The melano-macrophages in the spleen and kidney of herring in this study were yellow-green in colour. The presence of golden-yellow coloured macrophages and the enlargement of melano-macrophages due to extreme starvation are well-recognised phenomena (Roberts 1978). Consequently, this modified pigmentation may have been caused by starvation due to the severity of infection. This hypothesis can also be supported by the thin appearance of the host and the low levels of intestinal fat observed in the highly infected specimens.

With some exceptions, the host's reaction did not seem to have any, at least any immediate, lethal effects on the pathogen and even tightly surrounded spores were able to grow and form pseudohyphae. In the case of degeneration, however, loss of integrity of spore walls, condensation of the spore cytoplasm, loss of distinction between spore organelles and, in advanced stages, vacuolation and fragmentation of cytoplasm were observed. All the characteristics recorded in this study have been reported from plaice and haddock (McVicar \& McLay 1985). The conidia-like structures described by Ruggieri et al. (1970) from yellowtail flounder could have been degenerated spores. The capsules around degenerated spores appeared to be old, so degeneration could be due to the advanced age of the spore rather than to a direct influence of host defence mechanisms.

The pathogenicity of Ichthyophonus hoferi infection in herring, sprat and flounder is apparently due to the disruption in and atrophy of infected tissues caused by the growth and/or reproduction of spores. Additionally, in advanced stages of infection, the normal tissues of the infected organs are replaced either by granulomatous inflammation and necrosis or by a parasite mass which disrupts the usual function of the organs. For instance, infective plasmodia can be distributed through the brain and cerebellum. This phenomenon by itself or accompanied by progressive phases of infection in muscles or in the brain can cause 'Taumelkrankheit' or 'whirling disease' (Hofer 1893, Sindermann \& Scattergood 1954). These effects may cause the death of the host either directly through starvation or malfunction of the infected organs or indirectly by making the infected fish susceptible to predation.

Acknowledgements. I thank Prof. J. Thulin, Inst. Marine Research, Lysekil, Sweden, and Dr A. H. McVicar, Marine Lab, Aberdeen, Scotland, for their useful comments on this paper.

\section{LITERATURE CITED}

Agius C (1978) Infection by Ichthyophonus-like fungus in the deep sea scabbard fish Aphanopus carbo (Lowe) (Trichiuridae) in the North East Atlantic. J Fish Dis 1:191-193
Alderman DJ (1982) Fungal diseases of aquatic animals. In: Roberts RJ (ed) Microbial diseases of fish. Academic Press, London, p $189-242$

Bartnicki-Garcia S (1968) Cell wall chemistry, morphogenesis, and taxonomy of fungi. Annu Rev Microbiol 22:87-108

Bendele RA, Klontz GW (1975) Histopathology of teleost kidney diseases. In: Ribelin WE, Magaki G (eds) The pathology of fishes. University of Wisconsin Press, Madison, p 365-382

Bozzola JJ, Russell LD (1992). Electron microscopy; principles and techniques for biologists. Jones and Bartlett Publishers, Boston

Daniel GE (1933a) Studies on Ichthyophonus hoferi, a parasitic fungus of the herring, Clupea harengus. I. Parasite as it is found in the herring. Am J Hyg 17:262-276

Daniel GE (1933b) Studies on Ichthyophonus hoferi, a parasitic fungus of the herring, Clupea harengus. II. Gross and microscopic lesions produced by the parasite. Am J Hyg 17:491-501

Dorier A, Degrange C (1961) L'evolution de l'IChthyosporidium (Ichthyophonus) hoferi (Plehn and Mulsow) chez les salmonides d'elevage (truite arc en ciel et saumon de fontaine). Trav Lab Hydrobiol Piscic Univ Grenoble 52/53: $7-44$

Edelstein LM (1971) Melanin: a unique biopolymer. In: Ioachim HL (ed) Pathobiology annual. Appleton-CenturyCrofts, New York, p 309-324

Fish EF (1934) A fungus disease in fishes of the Gulf of Maine. Parasitology 26:1-16

Hodneland K, Karlsbakk E, Skagen DW (1997) Ichthyophonus hoferi in the Norwegian spring spawning herring (Clupea harengus L.). Evaluation of examination methods Inst Fiskeri Marinbiology Rapport 3:1-32

Hofer B (1893) Eine Salmoniden-Erkrankung. Allg Fisch-Ztg 18:168-171

Humason GL (1979) Animal tissue techniques, 4th edn. WH Freeman and Company, San Francisco

Lauckner G (1984) Diseases caused by microorganisms: agents: fungi. In: Kinne $O$ (ed) Diseases of marine animals, Vol 4, Part 1. Biologische Anstalt Helgoland, Hamburg, p $89-113$

Lillie RD (1951) Histochemical comparison of the Casella, Bauer, and periodic acid oxidation Schiff leucofuchsin technics. Stain Technol 26:123-136

Machado-Cruz JC, Eiras JC, Marques D (1982) Two new hosts (Mugil auratus and Blenius pholis) of IChthyosporidium and diagnosis in assimptomatic carrier. Publ Inst Zool 'Dr Augusto Nobre' Fac Cienc Porto 167:5-11

McVicar AH (1982) Ichthyophonus infections of fish. In: Roberts RJ (ed) Microbial diseases of fish. Academic Press, London, p 243-269

McVicar AH, McLay HA (1985) Tissue response of plaice, haddock and rainbow trout to the systemic fungus Ichthyophonus. In: Ellis AE (ed) Fish and shellfish pathology. The Crown, London, p 243-269

Miyazaki T, Kubota S (1977) Studies on Ichthyophonus disease of fish I. Rainbow trout fry. Bull Fac Fish Mie Univ 4: $45-56$

Noga EJ (1990) A synopsis of mycotic diseases of marine fishes and invertebrates. In: Snienszko SF, Axelord HR (eds) Pathology of fishes. Academic Press, San Diego, p $143-160$

Okamoto N, Nakase K, Suzuki H, Nakai Y, Fujii K, Sano T (1985) Life history and morphology of Ichthyophonus hoferi in vitro. Fish Pathol 20:273-285

Paperna I (1986) Ichthyophonus infection in grey mullets from Southern Africa: histological and ultrastructural study. Dis 
Aquat Org 1:89-97

Patterson KR (1996) Modelling the impact of disease-induced mortality in an exploited population: the outbreak of the fungal parasite Ichthyophonus hoferi in the North Sea herring (Clupea harengus). Can J Fish Aquat Sci 53 12: $2370-2887$

Plehn M, Mulsow K (1911) Der Erreger der 'Taumelkrankheıt' der Salmoniden. Zentralbl Bakteriol Parasitenkd Infektionskr Abt 1, 59:63-68

Ragan MA, Goggin CL, Richard JC, Cerenius L, Jamieson AVC, Plourde SM, Rand TG, Söderhäll K (1996) A novel clade of protistan near the animal-fungal divergence. Proc Natl Acad Sci USA 93:11907-11912

Rahimian H, Thulin J (1996) Epizootiology of Ichthyophonus hoferi in herring population of the Swedish west coast. Dis Aquat Org 27:187-195

Rand TG (1990) Studies of Ichthyophonus hoferi Plehn and Mulsow 1991, from Nova Scotian yellow tail flounder, Limanda ferruginea. PhD thesis, Dept Biol Univ New Brunswick

Roberts RJ (1975) Melanin-containing cells of teleost fish and their relation to diseases. In: Ribelin WE, Magaki G (eds) The pathology of fishes. University of Wisconsin Press, Madison, p 399-428

Roberts RJ (1978) Fish pathology. Bailliere Tindall, London Ruggieri GD, Nigrelli RF, Powles PM, Garnett DG (1970) Epi-

Editorial responsibility: David Bruno,

Aberdeen, Scotland, UK zootics in yellowtail flounder, Limanda ferruginea storer, in the western North Atlantic caused by Ichthyophonus, a ubiquitous parasitic fungus. Zoologica (NY) 55:57-62

Sindermann CJ (1990) Principal diseases of marine fish and shellfish. 2nd edn, Vol 1. Academic Press, New York

Sindermann CJ, Scattergood LW (1954) Diseases of fishes of western North Atlantic. II. IChthyosporidium disease of the sea herring (Clupea harengus). Maine Dep Sea Shore Fish, Res Bull 19:1-40

Sitja-Bobadilla A, Alvarez-Pellitero P (1990) First report of Ichthyophonus disease in wild and cultured sea bass, Dicentrarchus labrax, from the Spanish Mediterranean area. Dis Aquat Org 8:145-150

Spanggaard B (1993) Biological and technological aspects of Ichthyophonus hoferi infection in herring (Clupea harengus). Technical University, Lyngby, Denmark

Spanggaard B, Skouboe P, Rossen L (1996) Phylogenetic relationships of the intercellular fish pathogen Ichthyophonus hoferi and fungi, choanoflagellates and the rosette agent. Mar Biol 126:109-115

Sproston NG (1944) Ichthyosporidium hoferi (Plehn \& Mulsow), as internal fungoid parasite of the mackerel. J Mar Biol Assoc UK 26:72-98

Yasutake WT, Wales JH (1983) Microscopic anatomy of salmonids: an atlas. US Department of the Interior, Fish and Wildlife Service, Washington, DC

Submitted: September 29, 1997; Accepted: May 29, 1998

Proofs received from author(s): September 11, 1998 